\title{
Identification of an oncoprotein- and UV-responsive protein kinase that binds and potentiates the c-Jun activation domain
}

\author{
Masahiko Hibi, ${ }^{1}$ Anning Lin, ${ }^{1}$ Tod Smeal, ${ }^{1,2}$ Audrey Minden, ${ }^{1}$ and Michael Karin ${ }^{1,3}$ \\ Departments of ${ }^{1}$ Pharmacology and ${ }^{2}$ Biology, Center for Molecular Genetics, University of California San Diego, School of \\ Medicine, La Jolla, California 92093-0636 USA
}

The activity of c-Jun is regulated by phosphorylation. Various stimuli including transforming oncogenes and UV light, induce phosphorylation of serines 63 and 73 in the amino-terminal activation domain of c-Jun and thereby potentiate its trans-activation function. We identified a serine/threonine kinase whose activity is stimulated by the same signals that stimulate the amino-terminal phosphorylation of c-Jun. This novel c-Jun amino-terminal kinase (JNK), whose major form is $46 \mathrm{kD}$, binds to a specific region within the c-Jun trans-activation domain and phosphorylates serines 63 and 73. Phosphorylation results in dissociation of the c-Jun-JNK complex. Mutations that disrupt the kinase-binding site attenuate the response of c-Jun to Ha-Ras and UV. Therefore the binding of JNK to c-Jun is of regulatory importance and suggests a mechanism through which protein kinase cascades can specifically modulate the activity of distinct nuclear targets.

[Key Words: C-Jun; protein kinase; trans-activation function; phosphorylation]

Received June 29, 1993; revised version accepted August 24, 1993.

c-Jun, encoded by the c-jun protooncogene, is an important component of the dimeric, sequence specific, transcriptional activator AP-1 (for review, see Angel and Karin 1991). Like other activators, c-Jun is composed of two functional domains, a DNA-binding domain, which belongs to the bZIP class, located near its carboxyl-terminus and a trans-activation domain near its amino terminus (Angel et al. 1989; Bohmann and Tjian 1989; Smeal et al. 1989). While c-Jun expression is rapidly induced by extracellular signals, its activity is regulated post-translationally by protein phosphorylation (Angel et al. 1988; Angel and Karin 1991; Boyle et al. 1991; Karin and Smeal 1992). Phosphorylation of sites clustered next to the basic region of c-Jun inhibits DNA binding (Boyle et al. 1991; Lin et al. 1992; de Groot et al. 1993). Phosphorylation of two other sites, Ser-63 and Ser73 , located within the trans-activation domain potentiates the ability of c-Jun to activate transcription (Binetruy et al. 1991; Smeal et al. 1991). Whereas two of the inhibitory carboxy-terminal phosphorylation sites are phosphorylated by casein kinase II (CKII), an inhibitor of c-Jun activity (Lin et al. 1992), the kinase that phosphorylates the stimulatory amino-terminal sites remains to be identified (Hunter and Karin, 1992; Karin and Smeal, 1992). Analysis of c-Jun phosphorylation in vivo suggests

\footnotetext{
${ }^{3}$ Corresponding author.
}

that this kinase is activated by a pathway that transmits signals from cell-surface-associated tyrosine kinases, through Ha-Ras, to the nucleus (Smeal et al. 1992). In addition, irradiation of HeLa cells with ultraviolet (UV) light (Devary et al. 1992) and treatment of lymphoid and myeloid (but not fibroblasts or HeLa) cells with the tumor promoter TPA are expected to activate this kinase, as they also stimulate phosphorylation of Ser-63 and Ser73 (Pulverer et al. 1991, 1992; Adler et al. 1992a; Su and Y. Ben-Neriah, unpubl.).

Although the ERK/mitogen-activated protein (MAP) kinases were shown to phosphorylate the amino-terminal sites of c-Jun in vitro (Pulverer et al. 1991, 1992), these kinases were also shown to phosphorylate one of the inhibitory carboxy-terminal sites and display little or no activity toward the amino-terminal sites of c-Jun (Alvarez et al. 1991; Baker et al. 1992; Chou et al. 1992; A. Lin, unpubl.). Recently, a protein kinase was partially purified by binding to c-Jun affinity column and shown to phosphorylate the amino terminus of c-Jun but not v-Jun (Adler et al. 1992a). However, the relationship between this kinase, suggested to be $67 \mathrm{kD}$ in size, and other MAP kinases that phosphorylate c-Jun (Pulverer et al. 1991, 1992; Alvarez et al. 1992; Chou et al. 1992) is not clear; neither was this kinase shown to phosphorylate exactly the same sites that are phosphorylated in vivo. Here, we describe a serine/threonine kinase that binds to a defined subregion of the c-Jun activation do- 
main, whose major form is $46 \mathrm{kD}$ in size. This protein kinase phosphorylates c-Jun on Ser-63 and Ser-73 and is activated by the same agents that stimulate phosphorylation of these sites in vivo. Mutations that disrupt the kinase-binding site attenuate the response of c-Jun to UV and Ha-Ras in vivo. These and other findings strongly suggest that this serine/threonine kinase is the enzyme responsible for modulating the activity of the c-Jun trans-activation domain. Furthermore, they suggest a mechanism through which protein kinase cascades regulate the activity of nuclear transcription factors in a highly specific and efficient manner.

\section{A protein kinase binds and phosphorylates c-Jun}

We constructed a glutathione $S$-transferase (GST) fusion protein containing amino acids $1-223$ of $\mathrm{c}$-Jun. This protein, GSTcJun(wt), was bound through its GST moiety to glutathione (GSH)-agarose beads to generate an affinity matrix for identification of c-Jun-binding proteins. $\mathrm{Ha}$ ras transformation of FR3T3 cells results in increased phosphorylation of c-Jun on Ser-63 and Ser-73 (Binetruy et al. 1991; Smeal et al. 1991). Preliminary experiments indicated that the transformed cells contained higher levels of c-Jun amino-terminal kinase activity, whereas the levels of carboxy-terminal kinase activity remained unchanged (A. Lin unpubl.). To develop a convenient assay for the c-Jun amino-terminal protein kinase, we mixed nuclear and cytoplasmic extracts of untransformed and transformed FR3T3 cells with GSTcJun(wt)GSH-agarose beads. After extensive washing, proteins bound to the beads were incubated in kinase buffer in the presence of $\left[\gamma^{-32} \mathrm{P}\right]$ ATP and analyzed by SDS-polyacrylamide gel electrophoresis (SDS-PAGE). This resulted in phosphorylation of GSTcJun(wt), suggesting that a protein kinase bound to it and phosphorylated it while attached to GSH-agarose (Fig. 1). No phosphorylation of GST bound to GSH-agarose was detected. Because we wanted to identify a kinase that targets Ser-63 and Ser-73 of c-Jun, we repeated the experiment using a GSTcJun(Ala63/73) fusion protein, in which both of these serines were converted to alanines. Phosphorylation of this protein was lower than that of GSTcJun(wt) (Fig. 1). These findings are consistent with the higher level of c-Jun amino-terminal phosphorylation in transformed cells (Binetruy et al. 1991; Smeal et al. 1991, 1992). The kinase activity detected by this solid-phase assay was present in both the cytosolic and the nuclear fractions and was severalfold more abundant in the cytosol on a per-cell basis.

We used the solid-phase assay to examine amino-terminal c-Jun kinase activity in other cell types. Exposure of HeLa cells to UV activates Ha-Ras and results in a large increase in amino-terminal phosphorylation of c-Jun (Devary et al. 1992). Treatment of HeLa cells with TPA, on the other hand, has only a marginal effect on amino-terminal phosphorylation (Boyle et al. 1991). Extracts of unstimulated, UV- and TPA-treated HeLa cells were incubated with GSH-agarose beads loaded with either GSTcJun(wt), GSTcJun(Ala63/73), or GST, washed

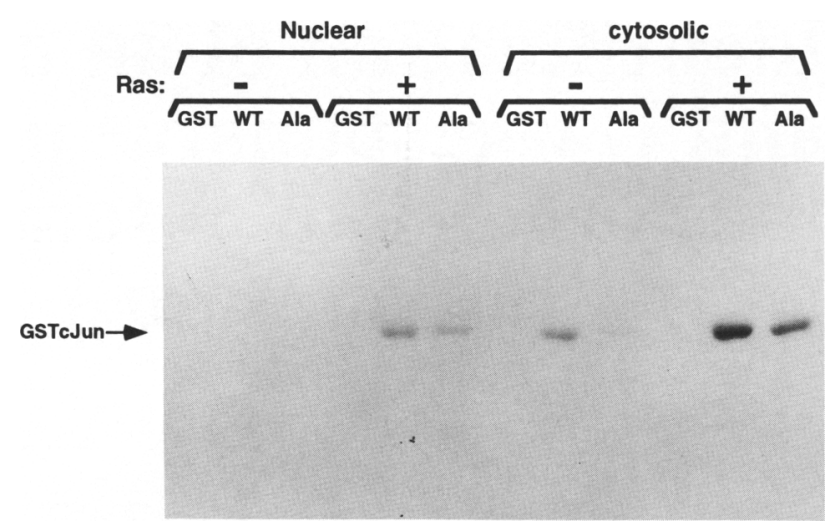

Figure 1. A protein kinase binds to GSTcJun-GSH-agarose beads. Equal numbers of FR3T3 $|-|$ and Ha-ras-transformed FR3T3 $1+\mid$ cells were kept in $0.5 \%$ FCS for $24 \mathrm{hr}$ and harvested to prepare nuclear and cytosolic extracts that were mixed with GSH-agarose beads containing $10 \mu \mathrm{g}$ of GST-cJun(wt), GSTcJun|Ala63/73), or GST. After $3 \mathrm{hr}$ the beads were spun down, washed four times and incubated in kinase buffer containing $\left[\gamma^{-32} \mathrm{P}\right] \mathrm{ATP}$ for $20 \mathrm{~min}$ at $30^{\circ} \mathrm{C}$. After elution in SDS sample buffer, the phosphorylated proteins were resolved by SDS-PAGE. The location of the GSTcJun fusion proteins is indicated. Similar results were obtained when protein concentration rather than cell number was used to normalize the amounts of extracts used in this assay.

extensively, and incubated with $\left[\gamma^{32}\right.$ P]ATP. Amino-terminal c-Jun kinase activity was elevated within $5 \mathrm{~min}$ after UV irradiation and was 250 -fold higher after $30 \mathrm{~min}$ than in unstimulated cells (Fig. 2A). The effect of TPA, however, was minor compared with that of UV. As found before, GSTcJun(wt) was phosphorylated more efficiently than GSTc)un(Ala63/73), whereas GST was not phosphorylated.

Recently, we found that TPA treatment of Jurkat T cells, unlike HeLa cells, increases phosphorylation of c-Jun on Ser-63 and Ser-73 (B. Su and Y. Ben-Neriah, unpubl.). In Jurkat cells, unlike HeLa cells, the aminoterminal kinase activity was strongly activated by TPA (Fig. 2B). This kinase also preferred GSTcJun(wt) over GSTcJun(Ala63/73) and did not bind to or phosphorylate the GST moiety. Collectively, these findings suggest that the kinase detected by the solid-phase assay phosphorylates c-Jun on Ser-63 and Ser-73 and that its regulation parallels that of $\mathrm{c}$-Jun amino-terminal phosphorylation.

\section{The bound kinase phosphorylates Ser- 63 and Ser-73}

To identify the phosphoacceptors used by the bound kinase, phosphorylated GSTcJun(wt), and GSTcJun(Ala63/ 73) were subjected to two-dimensional tryptic phosphopeptide mapping. The kinases isolated from Ha-rastransformed FR3T3 cells, UV-irradiated HeLa cells, and TPA-stimulated Jurkat cells, phosphorylated GSTcJun on $\mathrm{X}, \mathrm{Y}$, and two other peptides, $\mathrm{T} 1$ and $\mathrm{T} 2$ (Fig. 3A). X and $Y$ reflect phosphorylation of Ser-73 and Ser-63, re- 
A

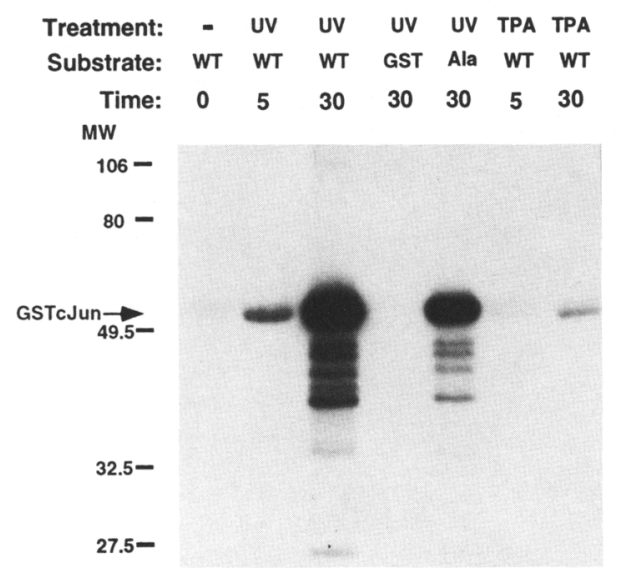

B

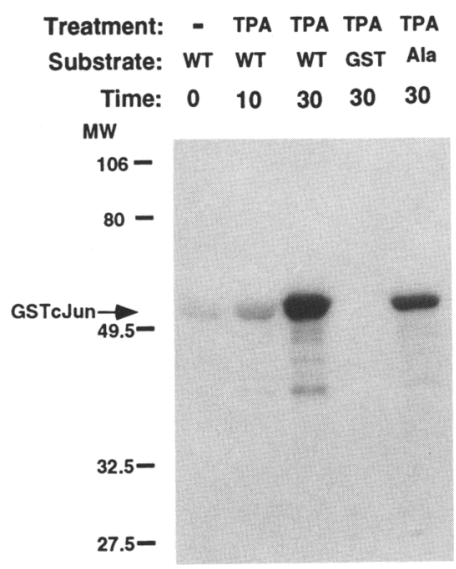

Figure 2. The kinase activity that binds to GSTcJun is inducible. $(A)$ HeLa S3 cells serum starved for $12 \mathrm{hr}$ were either left untreated, irradiated with UV-C $\left.(40) / \mathrm{m}^{2}\right)$, or incubated with TPA (100 ng/ml). Equal numbers of cells were harvested at the indicated times ( $\mathrm{min}$ ) after UV or TPA exposure. Whole-cell extracts [(WCEs) $\sim 800 \mu \mathrm{g}$ protein] were mixed with GSH-agarose containing $10 \mu \mathrm{g}$ of GST, GSTcJun(wt), or GSTcJun(Ala63/73). After 3 $\mathrm{hr}$ of incubation, followed by extensive washing, the solid-state phosphorylation assay was performed as described above. $(B)$ Jurkat cells were serum starved for $2 \mathrm{hr}$ and either left untreated or stimulated with TPA $(50 \mathrm{ng} / \mathrm{ml})$ for 10 or $30 \mathrm{~min}$. WCEs prepared from $5 \times 10^{6}$ cells were mixed with GSH-agarose containing GST, GSTcJun(wt), or GSTcJun(Ala63/ 73). Phosphorylation of the GST proteins attached to the beads was performed as described above. The faster moving bands are degradation products of GSTcJun.

spectively (Smeal et al. 1991) and were absent in digests of GSTcJun(Ala63/73), which contained higher relative levels of T1 and T2. Phosphoaminoacid analysis indicated that $\mathrm{T} 1$ and $\mathrm{T} 2$ contain only phosphothreonines, which by deletion analysis were assigned to Thr- 91 , Thr93 or Thr-95, all of which are followed by a Pro residue (M. Hibi, A. Lin, and T. Deng, unpubl.).

As described below, the bound kinase was eluted from the beads and used to phosphorylate full-length c-Jun in solution (Fig. 3B). As found in vivo the bound kinase phosphorylated c-Jun mostly on Ser-73, followed by Ser63. In addition, the bound kinase weakly phosphorylated c-Jun on two of its carboxy-terminal sites, resulting in the appearance of phosphopeptides b and $c$. At this lower kinase to substrate ratio, the threonine sites were phosphorylated to a very low extent. Because this was the first protein kinase that we could detect with clear specificity for at least one of the amino-terminal sites of c-Jun, we named it JNK [c-[un amino (N)-terminal protein kinase].

\section{INK binds tightly to c-Jun but is released by ATP}

To examine the stability of the c-Jun-JNK complex, extracts of TPA-stimulated Jurkat cells were incubated with GSTcJun(wt)-GSH-agarose beads. After extensive washing, the beads were eluted with increasing concentrations of $\mathrm{NaCl}$, urea, guanidine- $\mathrm{HCl}$ and SDS. Elution of JNK was examined by phosphorylation of c-Jun in solution. JNK was found to bind GSTcJun rather tightly; only a small fraction of kinase activity was eluted by 0.5 $\mathrm{M} \mathrm{NaCl}$; and even after elution with $2 \mathrm{M} \mathrm{NaCl}$, most of the kinase remained on the beads. Approximately $50 \%$ of the bound kinase was eluted by $1 \mathrm{~m}$ urea, and the rest was eluted by $2 \mathrm{M}$ urea (Fig. 4A). Nearly complete elution was achieved by either $0.5 \mathrm{M}$ guanidine- $\mathrm{HCl}$ or $0.01 \%$ SDS (data not shown). These conditions also resulted in partial elution of GSTcJun(wt), suggesting that the stability of the JNK-c-Jun complex is similar to that of the GST-GSH complex.

It is unlikely that JNK remains bound to phosphorylated c-Jun, because this would prevent phosphorylation of other proteins or dephosphorylation of c-Jun. Addition of exogenous c-Jun to kinase-loaded GSH-agarose beads to which GSTcJun was covalently linked results in its efficient phosphorylation (Fig. 4B, Lane 1). This suggests that after phosphorylating GSTcJun, JNK dissociates from it and can phosphorylate exogenous c-Jun. In addition, incubation in the presence of ATP resulted in elution of JNK from the beads, as indicated by its ability to phosphorylate exogenous c-Jun (Fig. 4B, Lanes 2-4). After incubation with $50 \mu \mathrm{M}$ ATP, $<20 \%$ of the kinase remained bound (cf. lanes 1 and 5 ).

\section{The major form of JNK is a $46-k D$ protein}

We used an in-gel kinase assay to determine the size of JNK and whether it is the major c-Jun amino-terminal kinase in the cell. The kinase was isolated from extracts of UV-stimulated HeLa cells on GSTcJun(1-79)-GSHagarose beads and was eluted with SDS sample buffer after extensive washing. The eluted proteins were resolved by SDS-PAGE on gels that were polymerized in the absence or presence of GSTcJun(wt). In addition, crude extracts of unstimulated and UV-stimulated HeLa cells were fractionated on the same gels. After electrophoresis, the proteins were renatured in the gel (see Materials and methods) and incubated in kinase buffer plus $\left[\gamma^{-32}\right.$ P]ATP. UV exposure activated two protein kinases, $46 \mathrm{kD}$ and $55 \mathrm{kD}$ in size, that phosphorylated GSTcJun in the gel (Fig. 5A). The same polypeptides were retained on beads loaded with GSTcJun(1-79) but not with GST (data not shown). We conclude that the $46-\mathrm{kD}$ polypeptide is the major, renatureable, c-Jun amino-terminal ki- 


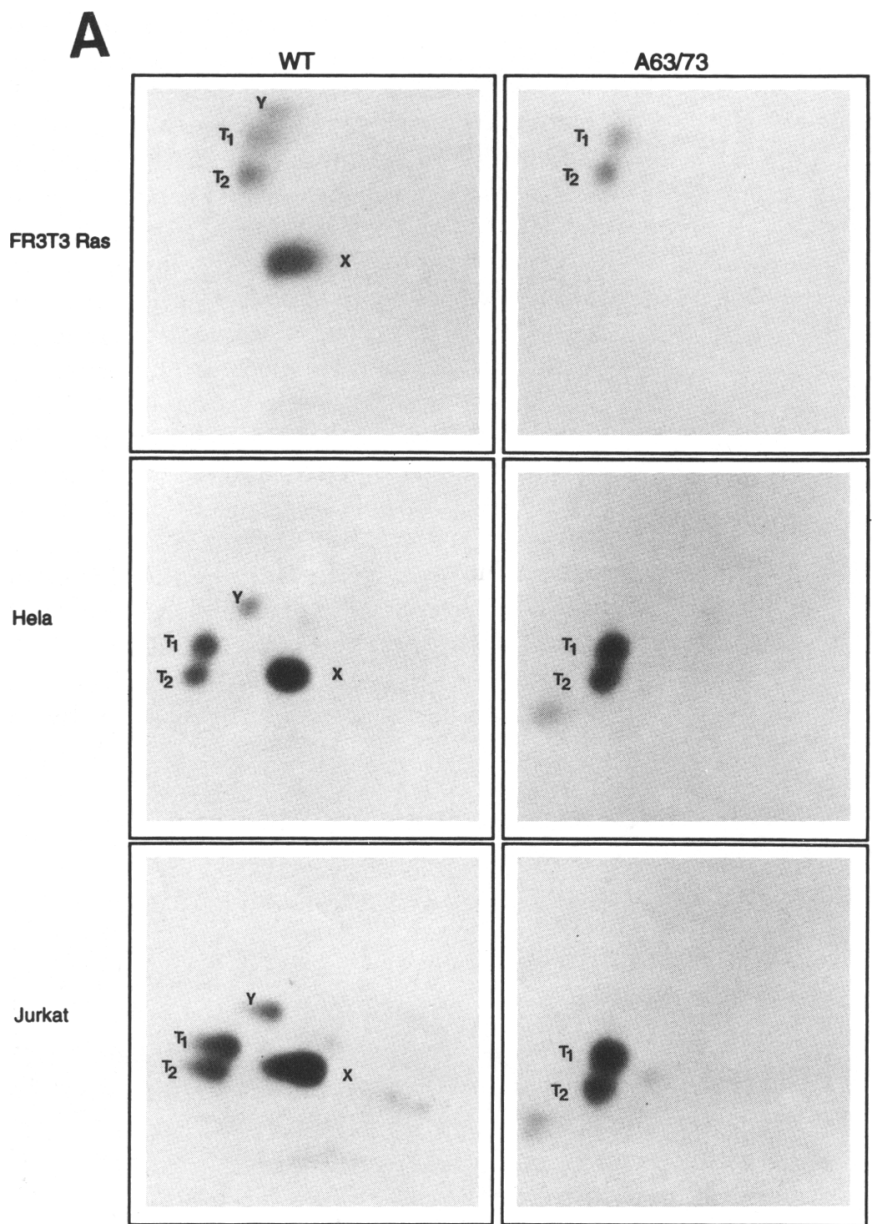

nase in the cell, and the second less abundant $55-\mathrm{kD}$ polypeptide, whose regulation is very similar isee Fig. $5 \mathrm{C})$, is a related protein kinase. Although the exact relationship between the two polypeptides is not clear, we refer to them as JNK-46 and JNK-55.

A further proof for the identity of the two polypeptides was provided by conventional renaturation studies. Extracts of TPA-stimulated Jurkat cells were incubated with GSTcJun(wt)-GSH-agarose beads, and the bound fraction was fractionated by SDS-PAGE. Renaturation, gel slicing, and elution revealed two renaturable c-Jun kinase activities, one migrating at $46 \mathrm{kD}$ and the second at $55 \mathrm{kD}$ (Fig. 5B). As found by the in-gel kinase experiments, the $46 \mathrm{kD}$ polypeptide was the more abundant form of JNK. Phosphopeptide mapping experiments indicated that this enzyme phosphorylated c-Jun on Ser-73 and Ser-63 (data not shown).

The in-gel kinase assay was used to examine extracts of K562 human erythroleukemia cells, U937 human histiocytic leukemia cells, Jurkat cells, HeLa cells, F9 embryonal carcinoma cells, Ha-ras-transformed FR3T3 cells and QT6 quail fibroblasts. The HeLa, F9, and QT6
B
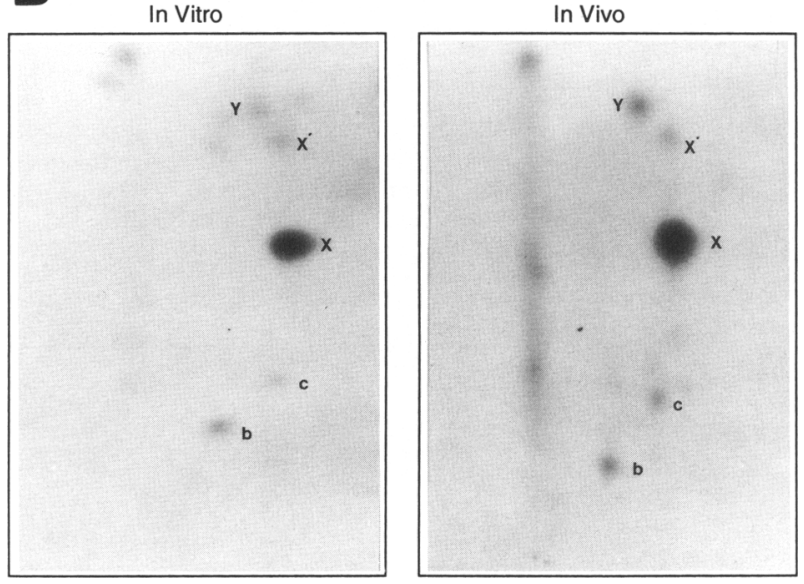

Figure 3. Phosphopeptide mapping of GST-cJun and c-Jun phosphorylated by JNK. (A) Maps of GSTcJun. WCEs of $\mathrm{Ha}$ ras-transformed FR3T3 cells $(2.5 \mathrm{mg})$, UV-irradiated HeLa cells $(200 \mu \mathrm{g})$, or TPA-stimulated Jurkat cells $(1.2 \mathrm{mg})$ were mixed with GSH-agarose containing either GSTcJun(wt) or GSTcJun(Ala63/73). The GSTcJun proteins were phosphorylated as described above by the bound kinase, isolated by SDSPAGE, excised from the gel, digested with trypsin, and subjected to two-dimensional phosphopeptide mapping. The X, Y, $\mathrm{T} 1$, and T2 phosphopeptides are indicated. The autoradiographs represent equal exposures. (B) Maps of c-Jun. Recombinant $c$-Jun was phosphorylated by INK eluted from GSTcJun(WT)-GSH-agarose beads. In addition, c-Jun was isolated by immunoprecipitation from ${ }^{32}$ p-labeled F9 cells cotransfected with c-Jun and $\mathrm{Ha}$-Ras expression vectors (Smeal et al. 1991). Equal counts of each protein preparation were digested with trypsin and subjected to phosphopeptide mapping. The migration positions of the $X, X^{\prime}$ (an alkylated derivative of X; Smeal et al. 1991) Y, b, and c phosphopeptides are indicated.

extracts were prepared from UV-irradiated cells and the U937 and Jurkat extracts were made from TPA-stimulated cells, whereas the $\mathrm{K} 562$ cells were not subjected to any special treatment. All cells contained JNK-46, and some, especially QT6 cells, also contained JNK-55 form (Fig. $5 \mathrm{C}$ ). The activities of both forms were induced by cell stimulation (data not shown).

\section{INK is a novel proline-directed inducible kinase}

The phosphoacceptors targeted by JNK are either Ser or Thr followed by a Pro. This property and its inducibility by extracellular stimuli suggested that INK may be related to ERK/MAP kinases (Rossomando et al. 1989; Boulton et al. 1991; Thomas 1992). Several members of this group, including pp42(ERK2), pp44(ERK1), and pp54, were reported to phosphorylate c-Jun on amino-terminal sites in vitro (Pulverer et al. 1991, 1992; Adler et al. 1992a). The MAP/ERK proteins are characterized by their ability to phosphorylate myelin basic protein (MBP). As shown in Figure 6A, purified ERK1/2 (a mixture of both enzymes provided by Dr. M. Cobb, South- 


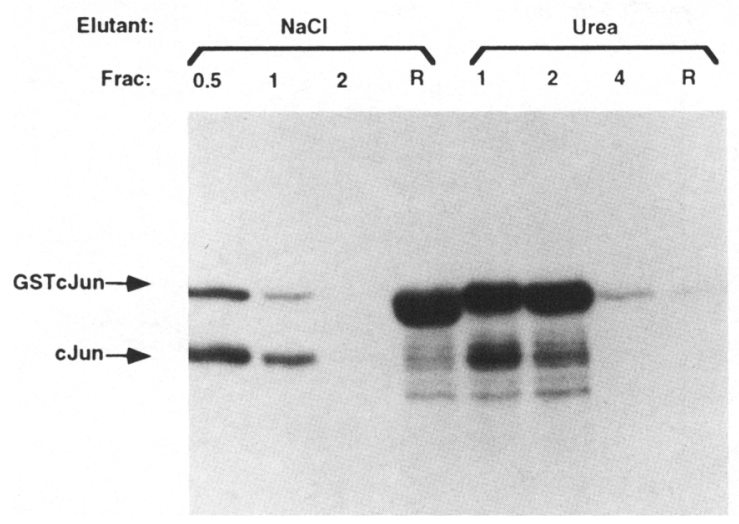

B

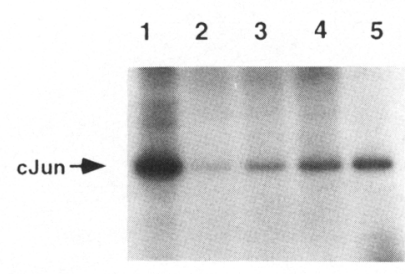

Figure 4. Elution of JNK from GSTcJun. $(A)$ GSTcJun(wt)-GSHagarose beads were incubated for 3 hr with WCE of TPA-stimulated Jurkat cells, and after four washes were subjected to elution in kinase buffer containing increasing concentrations of $\mathrm{NaCl}$ or urea (in molars). The eluted fractions (equal volumes) were dialyzed at $4^{\circ} \mathrm{C}$ against kinase buffer containing 10\% glycerol and no ATP and then incubated with recombinant c-Jun $(250 \mathrm{ng})$ in the presence of 20 $\mu \mathrm{M}$ ATP and $5 \mu \mathrm{Ci}\left[\gamma^{32} \mathrm{P}\right] \mathrm{ATP}$ for $20 \mathrm{~min}$ at $30^{\circ} \mathrm{C}$. The amount of $\mathrm{ki}$ nase remaining on the beads ( $R$ ) was determined by incubation of
min at $30^{\circ} \mathrm{C}$. The phosphorylated the isolated beads with kinase buffer in the presence of $20 \mu \mathrm{M} \mathrm{ATP}$ and $5 \mu \mathrm{Ci}$ of $\left[\gamma^{-32} \mathrm{P}\right] \mathrm{ATP}$ for 20 min at $30^{\circ} \mathrm{C}$. The phosphorylated
proteins were analyzed by SDS-PAGE as described above and visualized by autoradiography. The migration positions of GSTcJun and c-Jun are indicated. $(B)$ GSTcJun $(w t)$ was covalently linked to GSH-agarose beads, using cyanogen bromide, and incubated with WCEs of TPA-stimulated Jurkat cells. After extensive washing, parts of the beads were eluted with kinase buffer containing no ATP (lane 2), $20 \mu \mathrm{M}$ ATP (lane 3), or $50 \mu \mathrm{M}$ ATP (lane 4). The eluted fractions (equal volumes) were incubated with recombinant c-Jun (500 ng) as a substrate and $5 \mu \mathrm{Ci}$ of $\left[\gamma^{-32} \mathrm{P}\right] \mathrm{ATP}$ for $30 \mathrm{~min}$. In addition, the beads after elution with either kinase buffer alone (lane 1 ) or kinase buffer containing $50 \mu \mathrm{M} \mathrm{ATP}$ (lane 5) were incubated with c-Jun $\left(500 \mathrm{ng}\right.$ ) in the presence of $5 \mu \mathrm{Ci}$ of $\left[\gamma^{-32} \mathrm{P} \mid \mathrm{ATP}\right.$ for $30 \mathrm{~min}$. Phosphorylation of c-Jun was analyzed by SDS-PAGE and autoradiography.

western Medical Center) phosphorylated MBP 55-fold more efficiently than GSTcJun(wt), whereas JNK phosphorylated GSTcJun(wt) 25-fold more efficiently than MBP. In addition, INK phosphorylated GSTcJun(wt) 30fold more efficiently than GSTvJun(1-144), whereas ERK1/2 did not display significant preference for either substrate. We also examined the relationship between JNK and the pp54 MAP kinase. Whereas the MAP-2 kinase activity of pp54 is strongly stimulated by polylysine (Kyriakis and Avruch 1990), MAP-2 phosphorylation by JNK was not stimulated by polylysine (data not shown).

Further indications that JNK differs from previously characterized MAP/ERKs are provided by Western blotting experiments showing that JNK does not cross-react with an anti-ERK antiserum (a gift from Dr. M. Cobb) capable of detecting both ERK1 and ERK2 (Fig. 6B). In addition, probing of Western blots with two different anti-phosphotyrosine antisera (gifts from Drs. B. Sefton, Salk Institute, San Diego, CA, and J. Wang, University of California, San Diegol failed to detect the presence of this phosphorylated residue in JNK, whereas ERK1 was clearly reactive (Fig. 6; results shown for only one antiserum). Even a 10-fold longer exposure failed to detect staining of either JNK-46 or JNK-55. Because previously characterized ERK/MAP kinases are tyrosine phosphorylated (Rossomando et al. 1989; Kyriakis and Avruch 1990; Boulton et al. 1991), these results suggest that JNK is a novel proline-directed extracellular signal-responsive kinase.

\section{Definition of the kinase-binding site}

We used deletions of GSTcJun lacking either amino- or carboxy-terminal sequences (Fig. 7A) to define the JNKbinding site. These proteins were immobilized on GSH- agarose beads and incubated with an extract of UV-irradiated HeLa cells. Binding of JNK was examined by its ability to phosphorylate the GSTcJun fusion proteins, all of which contained both Ser-63 and Ser-73 (Fig. 7B). To exclude the possibility that any of the truncations affected presentation of the amino-terminal phosphoacceptors without affecting JNK binding, we also examined whether JNK eluted from these beads can phosphorylate exogenous c-Jun in solution (Fig. $7 \mathrm{C}$. The results obtained by both assays indicated that removal of amino acids 1-21 had no effect on JNK binding. Removal of amino acids $1-32$ resulted in a large decrease in phosphorylation of GSTcJun but only a three-fold decrease in JNK binding. Removal of amino acids 1-42, however, completely eliminated JNK binding. The two carboxyterminal truncations that were examined had no effect on JNK binding, and a fusion protein containing amino acids 1-79 of c-Jun exhibited full binding activity. Hence, amino acids 33-79 constitute the kinase-binding site.

The JNK-binding site encompasses the $\delta$ region, spanning amino acids 31-57 of c-Jun, which are deleted in v-Jun (Vogt and Bos 1990). To determine the involvement of the $\delta$ region in JNK binding, we constructed GST fusion proteins containing the amino-terminal region of chicken c-Jun (amino acids 1-144) or v-Jun (Fig. 8A). Binding assays were performed as described above. Whereas chicken GSTcJun bound INK as efficiently as human GSTcJun, GSTvJun was defective in JNK binding (Fig. 8B,C).

\section{INK binding is required for Ha-Ras and UV responsiveness}

Phosphorylation of Ser-63 and Ser- 73 potentiates c-Jun- 
Hibi et al.

A

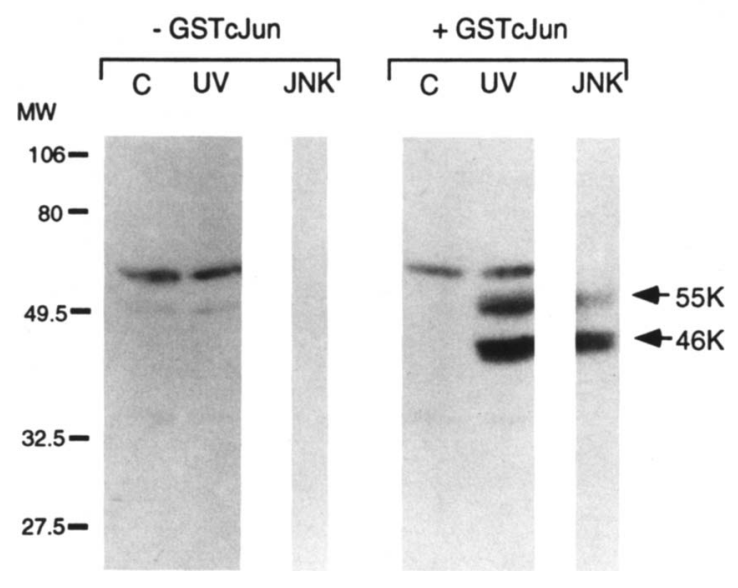

C

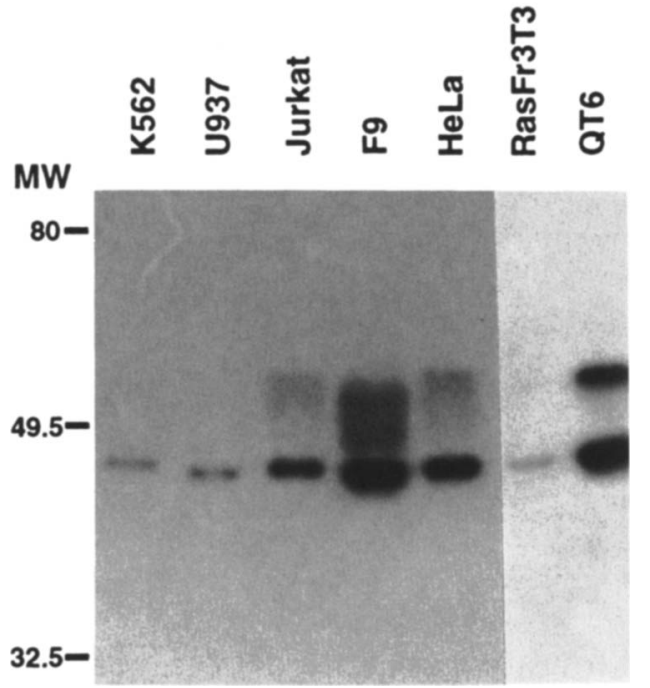

B

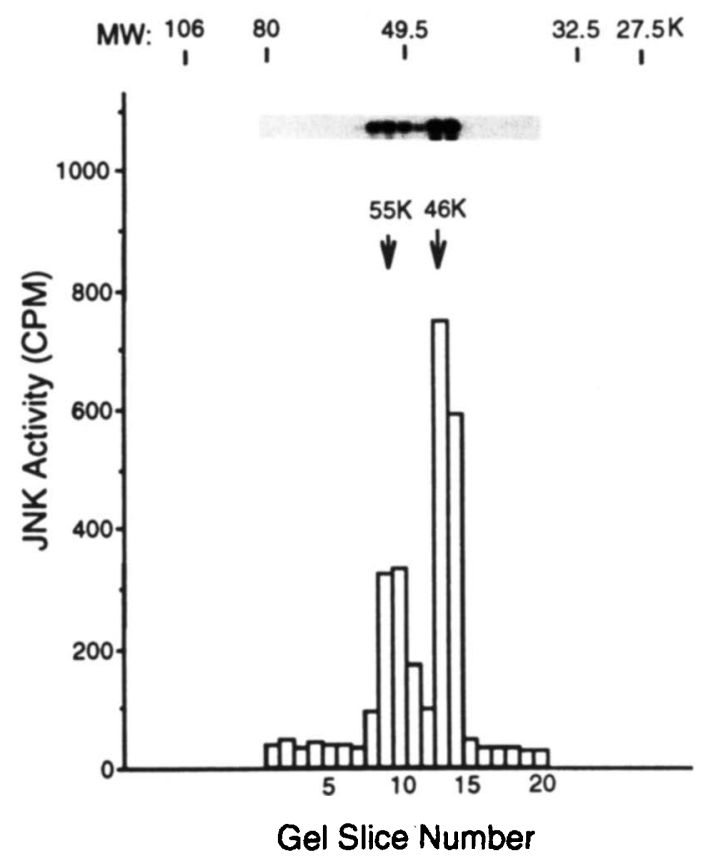

Figure 5. Identification of the INK polypeptides. $(A)$ In-gel kinase assay. WCEs $(200 \mu \mathrm{g})$ of UV-irradiated (UV) or non-irradiated (C) HeLa S3 cells and the bound fraction (JNK), isolated by applying $400 \mu \mathrm{g}$ of WCEs of UV-irradiated HeLa cells to GSTcJun(1-79)-GSH-agarose, were separated by SDS-PAGE on gels that were polymerized in the absence or presence of GSTcJun(wt). After electrophoresis, the gel was incubated in $6 \mathrm{M}$ urea and subjected to renaturation as described in Materials and methods. The renatured gels were incubated in kinase buffer containing $50 \mu \mathrm{M}$ ATP and $5 \mu \mathrm{Ci} / \mathrm{ml}$ of $\left[\gamma^{-32} \mathrm{P}\right] \mathrm{ATP}$ for $1 \mathrm{hr}$ at $30^{\circ} \mathrm{C}$, washed, fixed, and visualized by autoradiography. $(B)$ Elution of JNK after SDS-PAGE. GSTcJunGSH-agarose beads were incubated with WCEs of TPA-stimulated Jurkat cells. After washing, the bound proteins were eluted in SDS sample buffer and separated by SDS-PAGE. The gel was subjected to renaturation, followed by horizontal slicing. Gel slices were homogenized in kinase buffer containing $0.1 \mathrm{mg} / \mathrm{ml}$ of BSA and incubated at $4^{\circ} \mathrm{C}$ for $16 \mathrm{hr}$. The eluates were used to assay JNK activity using GSTcJun(wt) as a substrate. The phosphoproteins were analyzed by SDSPAGE and visualized by autoradiography, and the level of kinase activity was determined by Cerenkov counting of the sliced gel. Shown is a portion of the autoradiograph and the level of GSTcJun kinase activity in each slice. (C) In-gel kinase assays. GSTcJun(WT)-GSH-agarose beads were incubated with WCEs of logarithmically growing K562 and Ha-ras-transformed FR3T3 cells, TPA-stimulated Jurkat, and U937 cells and UV-irradiated HeLa, F9, and QT6 cells. After washing, the bound proteins were eluted and analyzed by in-gel kinase assay as described above. The slight differences in electrophoretic mobilities of the INK polypeptides are attributable to the loading of different protein amounts on each lane.

mediated trans-activation in response to Ha-Ras and UV (Smeal et al. 1991; Devary et al. 1992). If binding of JNK has any role in this response, mutations that decrease binding should attenuate the stimulation of c-Jun activity. This relationship was examined by cotransfection assays using chimeric GAL4-cJun and GAL4-vJun expression vectors, encoding the DNA-binding domain of the yeast activator GAL4 (Sadowski and Ptashne 1989) and amino-terminal sequences of c-Jun or v-Jun. The ability of these chimeras to activate the GAL4-dependent reporter 5xGAL4-E1b-CAT (Lillie and Green 1989) was examined in the absence or presence of a cotransfected $\mathrm{Ha}$-Ras expression vector (Fig. 9A) or UV irradia- tion (Fig. 9B). Whereas deletion of amino acids $1-32$ of c-Jun resulted in a small decrease in Ha-Ras responsiveness, deletion of amino acids $1-42$ or $1-55$ resulted in a large decrease in Ha-Ras and UV responsiveness. A similar decrease in Ha-Ras and UV responsiveness was observed upon substitution of c-Jun sequences with v-Jun sequences. The GAL4-cJun(56-223) and GAL4-vJun chimeras were only two-fold more responsive than GAL4 cJun(1-246;Ala63/73), in which Ser-63 and Ser-73 were converted to alanines. Western blotting indicates that all of these proteins accumulate to a similar extent $(\mathrm{B} . \mathrm{Su}$, unpubl.).

To reveal the role of JNK binding in c-Jun phosphory- 
A

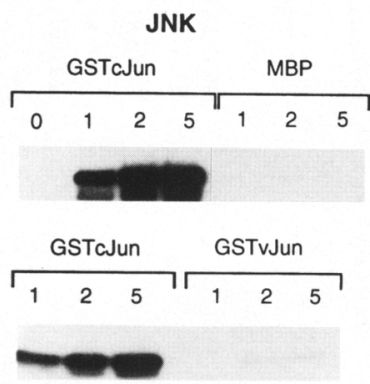

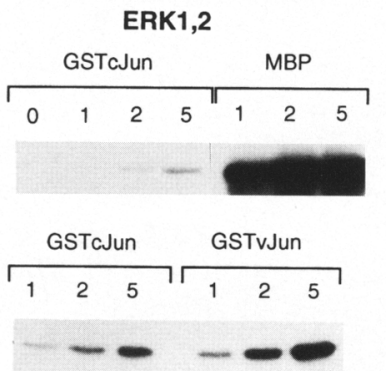

B

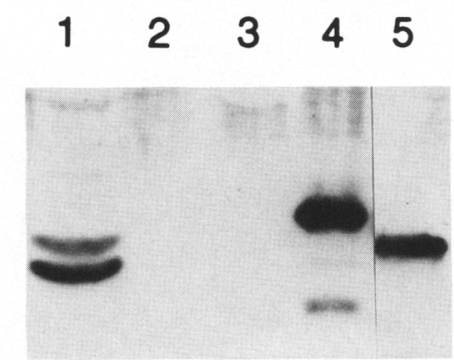

C

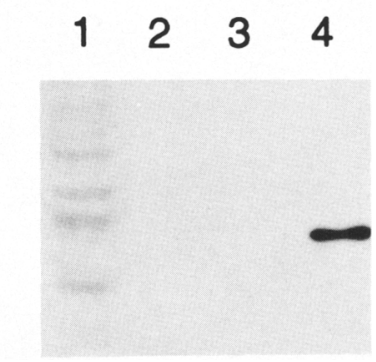

Figure 6. INK is different from previously described MAP kinases. (A) Substrate specificity. After incubation of GSTcJun-GSHagarose beads with WCEs of UV-irradiated HeLa cells and washing, the JNK fraction was eluted with $2 \mathrm{M} \mathrm{NaCl}$. JNK and a purified MAP kinase preparation that contains both ERK1 and ERK2 (from Dr. M. Cobb) were examined for their ability to phosphorylate GSTcJun(wt), GSTvJun, and MBP as substrates. The phosphorylated proteins were resolved by SDS-PAGE and visualized by autoradiography. The exposure time for the autoradiograph comparing GSTcJun with GSTvJun phosphorylation by ERK1/2 (right) is 10 times longer than for the corresponding one comparing the phosphorylation of these substrates by JNK (left). The numbers refer to the amount of substrate protein in micrograms. $(B)$ Western blotting with anti-ERK1/2 antiserum. WCEs (100 $\mu$ g) of UV-irradiated HeLa cells (lane 1), the eluted fraction of GSTcJun(1-79) bound to GSH-agarose in the absence of cell extract (lane 2), a JNK fraction isolated from $2 \mathrm{mg}$ of WCE of UV-irradiated HeLa cells using GSTcJun(1-79)-GSH-agarose lequivalent to the amount of JNK present in 200 $\mu \mathrm{g}$ of WCE; lane 3), recombinant His-tagged ERK1 (50 ng; lane 4), and recombinant His-tagged ERK2 (50 ng; lane 5) were resolved by SDS-PAGE and subjected to Western blotting using an antiserum that reacts with both ERK1 and ERK2. (C) Western blotting with anti-phosphotyrosine antiserum. WCEs $(100 \mu \mathrm{g})$ of UV-irradiated HeLa cells (lane 1), the eluted fraction of GSTcJun(1-79)-GSHagarose in the absence of WCEs (lane 2), a JNK fraction isolated from $2 \mathrm{mg}$ of WCEs of UV-irradiated HeLa cells (equivalent to the amount of JNK present in $200 \mu \mathrm{g}$ of WCEs; lane 3), and recombinant His-tagged ERK1 (50 ng; lane 4) were subjected to Western blotting using affinity-purified rabbit polyclonal anti-phosphotyrosine antibodies (from Dr. B. Sefton). The same results were obtained using a monoclonal anti-phosphotyrosine antibody (506 from Dr. J. Wang).

lation we cotransfected c-Jun and v-Jun expression vectors into F9 cells in the absence or presence of an activated $\mathrm{Ha}$-ras allele or UV irradiation. Immunoprecipitation from ${ }^{35} \mathrm{~S}$-labeled cells showed that c-Jun and v-Jun were expressed at similar levels that were not affected by either Ha-Ras (Fig. 10A) or UV (Fig. 10B). Immunoprecipitation from ${ }^{32} \mathrm{P}$-labeled cells indicated that both Ha-Ras and UV stimulated phosphorylation of c-Jun, whereas phosphorylation of $\mathrm{v}$-Jun, with a basal level severalfold lower than that of c-Jun, was not enhanced by either treatment. As noticed earlier (Devary et al. 1992), UV was a stronger inducer of c-Jun phosphorylation, resulting in its retarded electrophoretic mobility. Phosphopeptide mapping confirmed that Ha-Ras expression had a much lesser effect on the phosphorylation of v-Jun in comparison with its effect on c-Jun (data not shown).

\section{Discussion}

Phosphorylation of Ser-63 and Ser-73 in the amino-terminal activation domain of c-Jun in response to expression of transforming oncogenes or UV irradiation augments its transcriptional activity (Binetruy et al. 1991; Smeal et al. 1991, 1992; Devary et al. 1992; Karin and Smeal, 19921. Here, we characterize a protein kinase that is activated by Ha-Ras and UV and is responsible for phosphorylation of c-Jun on Ser-63 and Ser-73. This protein kinase, JNK, binds to a distinct site within the amino-terminal activation domain of c-Jun, the integrity of which is required for optimal Ha-Ras and UV respon- siveness. The binding of JNK to c-Jun provides a novel mechanism for increasing the efficacy and specificity of signal transduction from the cell surface to the nucleus.

\section{Identification of the c-Jun amino-terminal kinase}

Several protein kinases were claimed to phosphorylate c-Jun on Ser-63 and Ser-73. The MAP kinases ERK1, ERK2, and pp54 were reported to phosphorylate these sites in vitro (Pulverer et al. 1991). However, other investigators find that both ERK1 and ERK2 and the closely related ERT phosphorylate Ser-243 in the carboxyl terminus of c-Jun rather than the two amino-terminal sites (Alvarez et al. 1991; Baker et al. 1992; Chou et al. 1992; A. Lin unpubl.). Only after deletion of the carboxy-terminal sites did ERK1 and ERK2 phosphorylate the amino-terminal sites of c-Jun (A. Lin unpubl.), and even that was relatively inefficient in comparison with their MBP kinase activity. Like ERK1 and ERK2, pp54 phosphorylates MBP (Kyriakis and Avruch 1990) and therefore is expected to contribute to total MBP kinase activity. However, total MBP kinase activity is not regulated in the same manner as c-Jun phosphorylation (A. Minden unpubl.). Another kinase that phosphorylates Ser-63 and Ser-73 in vitro is cdc2 (Baker et al. 1992). However, c-Jun phosphorylation is not cell cycle dependent (T. Hunter, pers. comm.). Recently, a protein kinase was partially purified on a GSTclun affinity column and reported to phosphorylate Ser-63 and Ser-73 of c-Jun (Adler et al. 1992a,b). However, only an amino-terminal 
Figure 7. Delineation of the JNK-binding site. $|A|$ GSTcJun fusion proteins containing various c-Jun sequences were expressed in E. coli and isolated on GSH-agarose. The bound proteins were analyzed by SDS-PAGE and stained with Coomassie blue. Numbers indicate the amino acids of c-Jun present in each fusion protein, the migration positions of which are indicated by dots. Faster migrating bands are degradation products. $(B)$ WCEs of UV-irradiated HeLa S3 cells were mixed with GSH-agarose containing equal amounts of the GST fusion proteins shown above. After washing, the beads were incubated for $20 \mathrm{~min}$ in kinase buffer containing $\left[\gamma^{-32} \mathrm{P}\right]$ ATP. The GST fusion proteins were eluted from the beads and analyzed by SDS-PAGE and autoradiography. The migration positions of the intact GST fusion proteins are indicated by dots. $(C)$ After incubation with WCEs of UV-irradiated HeLa cells and washing, part of the bound JNK fraction was eluted with $1 \mathrm{M} \mathrm{NaCl}$ and examined for its ability to phosphorylate recombinant c-Jun $(250 \mathrm{ng})$ in solution. Protein phosphorylation was analyzed by SDS-PAGE and autoradiography.

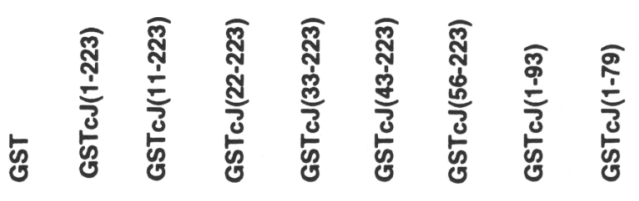

A. Protein Gel

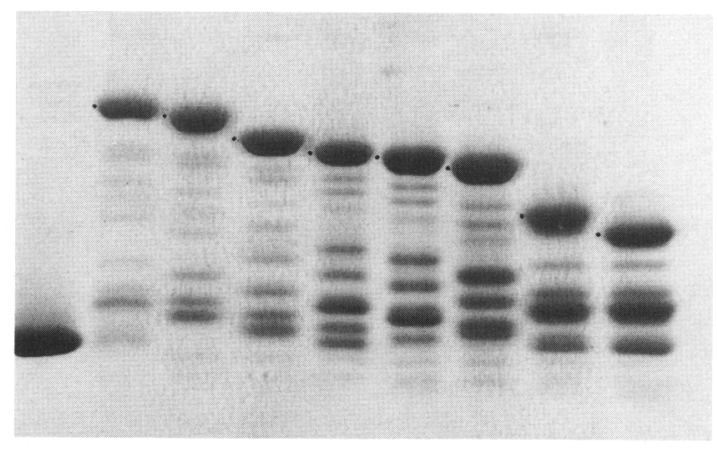

B. ${ }^{32}$ P-Immobilized Substrate

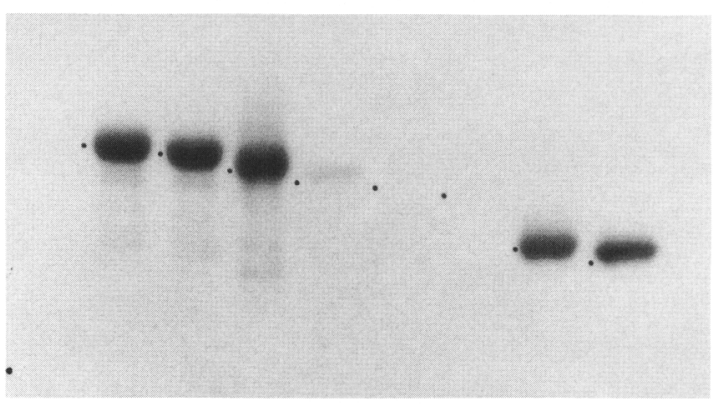

C. ${ }^{32}$ P-Exogenous Substrate

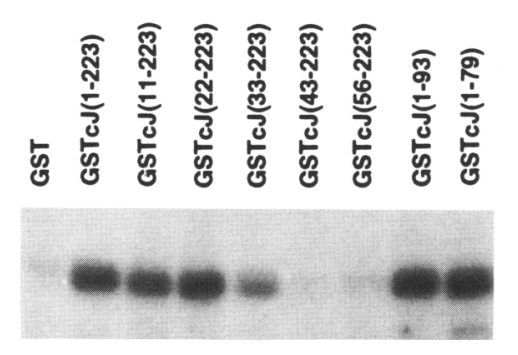

fragment of c-Jun was examined as a substrate for that kinase, and the actual phosphorylation sites have not been mapped. That protein kinase was suggested to be 67 $\mathrm{kD}$ in size. These investigators also reported the purification of ERK1 and ERK2 as c-Jun kinases (Pulverer et al. 1992|, and the relationship between the c-Jun-bound kinase and the latter two was not determined.

Clearly, any protein kinase that phosphorylates c-Jun in vivo should exhibit properties consistent with this role. In vivo, the amino- and carboxy-terminal phosphorylation sites of c-Jun are modulated by separate pathways (for review, see Karin and Smeal 1992). Only amino-terminal phosphorylation is stimulated by expression of transforming oncogenes (Binetruy et al. 1991; Smeal et al. 1991, 1992), UV irradiation (Devary et al. 1992), or TPA treatment of myeloid and lymphoid cells (Pulverer et al. 1991, 1992; B. Su and Y. Ben-Neriah unpubl.). The serine/threonine kinase INK, identified by its ability to bind to the activation domain of c-Jun, exhibits this specificity and phosphorylates the physiological amino-terminal sites. When bound to GSTcJun, JNK also phosphorylates Thr-91, Thr-93 or Thr-95 of c-Jun, which are also phosphorylated to a low extent in c-Jun isolated from UV-irradiated HeLa cells (Devary et al. 1992). Even phosphorylation of Ser-63 in most cases is lower than that of Ser-73 (Binetruy et al. 1991; Smeal et al. 1991, 1992). Only in UV-irradiated cells or after solid-phase kinase assay, its phosphorylation approaches that of Ser73. All of the JNK phosphoacceptor sites contain Ser or Thr followed by a Pro, which in the case of the major sites is followed by a negatively charged residue. Unlike known members of the MAP/ERK group, JNK phosphorylates MBP much less efficiently than c-Jun.

The most effective stimulator of c-Jun amino-terminal phosphorylation in HeLa cells is UV light (Devary et al. 1992). The same agent is also the most effective stimulator of JNK activity measured in vitro. On the other hand, TPA has only a slight effect on amino-terminal 
A

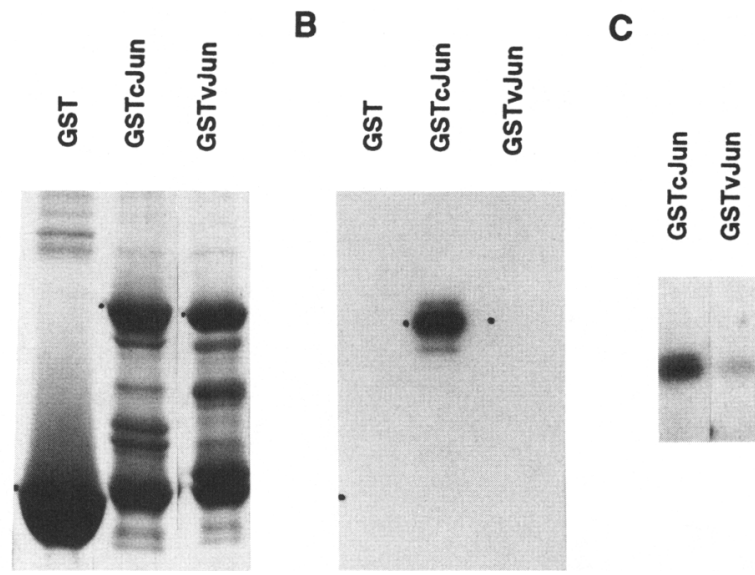

Figure 8. v-Jun is defective in JNK binding. $(A)$ The activation domain (amino acids 1-144) of chicken (Ch) c-Jun and the equivalent region of v-Jun were fused to GST and expressed in E. coli. GST fusion proteins were isolated on GSH-agarose and analyzed by SDS-PAGE and Coomassie blue staining. The migration positions of the intact proteins are indicated by dots. $(B)$ Extracts of TPA-activated Jurkat cells were incubated with GSH-agarose containing GST, GSTcJun(Ch), or GSTvJun. After washing, the beads were incubated in kinase buffer containing $\left[\gamma^{-32} \mathrm{P}\right] \mathrm{ATP}$, and the phosphorylated GST fusion protein was analyzed as described in Fig. 7. $(C)$ The bound fraction was eluted from the GSTcJun(Ch) and GSTvJun beads and analyzed for its ability to phosphorylate c-Jun in solution, as described in Fig. 7.

phosphorylation of c-Jun in HeLa cells or human fibroblasts (Boyle et al. 1991) and is also a poor activator of INK in these cells. However, TPA is much more efficient than UV in activating MBP kinase (A. Minden unpubl.). Therefore, none of the TPA-inducible MBP kinases can make a significant contribution to amino-terminal phosphorylation of c-Jun in HeLa cells or human fibroblasts. TPA treatment of Jurkat $T$ cells, however, does stimulate amino-terminal phosphorylation (B. Su and Y. BenNeriah unpubl.) and is also an effective stimulator of JNK. The magnitude and the kinetics of JNK activation are also consistent with changes in c-Jun phosphorylation in living cells. In addition to UV in HeLa cells and TPA in Jurkat cells, the amino-terminal phosphorylation of c-Jun is increased upon transformation of rat fibroblasts by Ha-ras (Binetruy et al. 1991). Ha-ras transformation results in higher JNK activity.

Additional evidence for the role of JNK in c-Jun phosphorylation is provided by disruptions of its binding site, which decrease the stimulation of c-Jun transcriptional activity and phosphorylation by Ha-Ras and UV. Although both JNK and the kinase described by Adler et al. (1992a) preferentially phosphorylate the amino-terminal domain of c-Jun over v-Jun, ERK1 does not exhibit such a preference. We also find that in FR3T3 cells a portion of JNK is nuclear. A nuclear location is consistent with the expected site of action of a c-Jun kinase.

Although JNK is activated by extracellular stimuli and its phosphoacceptors are followed by prolines, we failed to detect the presence of phosphotyrosine in both forms of JNK; neither was it recognized by anti-ERK antibodies. On the basis of all of these criteria we conclude that INK is the most likely protein kinase to phosphorylate the amino-terminal sites of c-Jun in response to transforming oncogenes and UV irradiation and that it is a novel inducible proline-directed kinase.

\section{Biological significance and implications}

The INK-binding site encompasses amino acids 33-79 of c-Jun. Deletion of amino acids 1-42 or 31-57 (as in v-Jun) results in a complete loss of JNK binding and a large decrease in the response of c-Jun to Ha-Ras and UV. These findings strongly suggest that INK binding to c-Jun is important for modulation of its activity by the Ha-Ras pathway.

The relationship between the loss of JNK binding and v-Jun activity is less clear. Removal of the $\delta$ region increases the transforming activity of c-Jun in chicken embryo fibroblasts (CEFs) but decreases its transcriptional activity in both CEFs and F9 cells (Bos et al. 1990; Håvarstein et al. 1992). This led Vogt and co-workers to derive an inverse correlation between transformation and trans-activation in CEF and suggest that increased transforming activity of $v$-Jun could be attributable to its failure to activate transcription of growth-attenuating genes that require high c-Jun activity (Håvarstein et al. 1992). It is therefore possible that by increasing c-Jun activity, JNK may be involved in negative growth control in CEF. These results, however, do not apply to rat embryo fibroblasts (REFs), where there is a direct correlation between trans-activation by various c-Jun mutants and their transforming activity (Alani et al. 1991). Furthermore, in that system c-jun is a much more potent oncogene than v-jun (M. Birrer, pers. comm.). Because phosphorylation of Ser-63 and Ser-73 is required for oncogenic cooperation between Ha-Ras and c-Jun (Smeal et al. 1991), it is likely that in REF, JNK is involved in positive growth control.

Loss of the $\delta$ region was reported to increase the activation potential of c-Jun (Baichwal and Tiian 1990; Baichwal et al. 1991). Because this effect was observed only in some cell types (Baichwal and Tjian 1990) but not in F9 or NIH-3T3 cells (Imler et al. 1988; Angel et al. 1989), it was attributed to a cell type-specific repressor (Baichwal and Tjian 1990). This repressor, however, has not been identified, and more recently, a second region, $\epsilon$ (amino acids 110-137), was suggested to be its primary binding site (Baichwal et al. 1992). Although in certain cell types, binding of inactive INK may directly repress c-Jun activity or stabilize the interaction of the putative repressor with the $\epsilon$ region, this does not apply to F9 or NIH-3T3 cells, in which c-Jun is a more potent activator than v-Jun (Binetruy et al. 1991; Imler et al. 1988).

So far we were not able to coprecipitate JNK with c-Jun (M. Hibi unpubl.). However, the only assay currently available for demonstrating association of JNK with c-Jun is based on its kinase activity. Because in nonstimulated cells JNK has very low basal activity, its detection requires cell stimulation, but this should result in dis- 
Figure 9. The JNK-binding site is required for optimal Ha-Ras and UV responsiveness. (A) Ha-Ras. F9 cells were cotransfected with expression vectors (1 $\mu \mathrm{g}$ ) encoding the indicated GAL4-cJun chimeric proteins, containing various portions of the c-Jun activation domain [c], amino acids 1-223; 33,33-223; 43,43-223; 56,56-223; A63,73,1-246|Ala63/73)], and a 5xGAL4-Elb-CAT reporter $(2 \mu \mathrm{g})$ in the absence or presence of the indicated amounts (in $\mu g$ ) of pZIP. NeoRas(Leu-61). The total amount of expression vector was kept constant, and the total amount of transfected DNA was brought to $15 \mu \mathrm{g}$ using pUC18 and pZIPNeo. Cells were harvested $28 \mathrm{hr}$ after transfection, and CAT activity was determined. Shown are the averages of two experiments, calculated as fold activation over the level of reporter expression seen in the absence of the GAL4-Jun expressions vectors. $(B)$ UV. F9 cells were transfected as described above except that instead of cotransfection with pZIPNeoRas, the cells were either exposed or not exposed to $40 \mathrm{~J} / \mathrm{m}^{2}$ of UV-C $8 \mathrm{hr}$ after transfection. The cells were harvested and assayed for CAT activity $20 \mathrm{hr}$ later. Shown are the averages of two experiments calculated as described above.

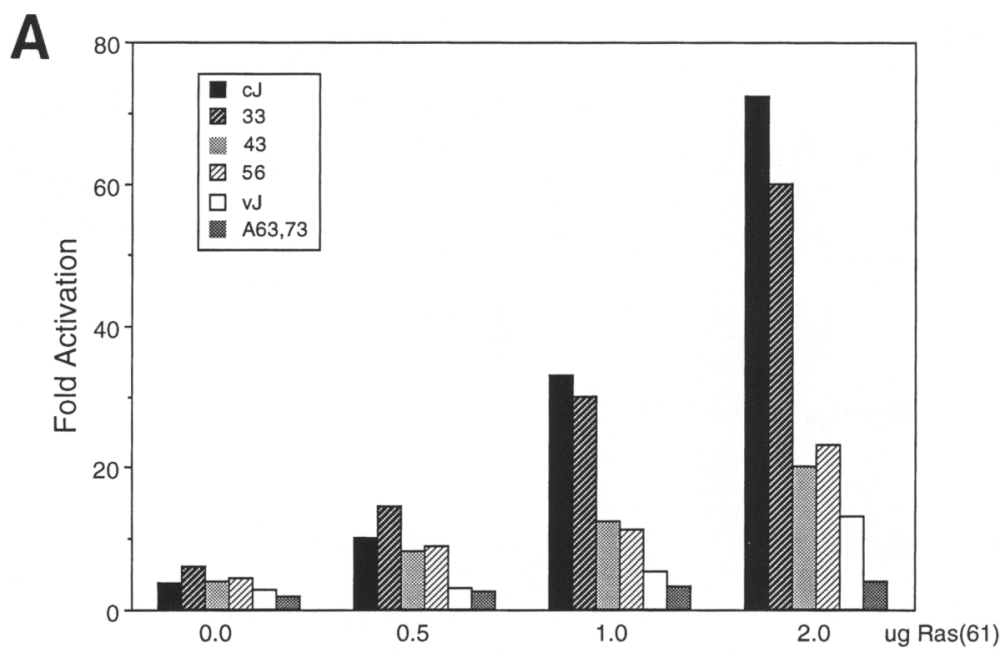

B

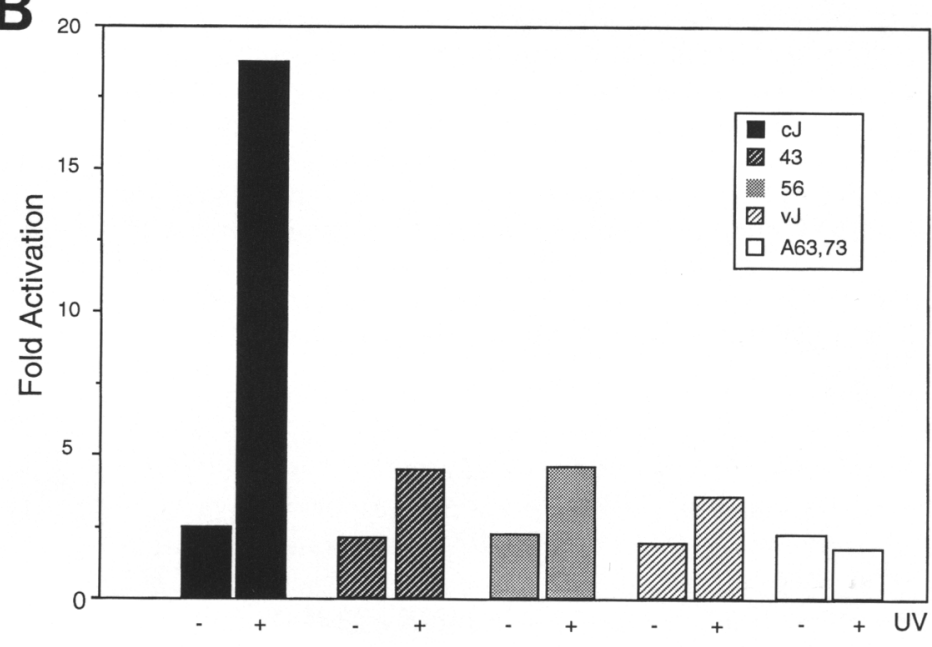

sociation of the JNK-c-Jun complex as a result of c-Jun phosphorylation. Demonstration of in vivo association between JNK and c-Jun will therefore require anti-JNK antibodies. Nevertheless, the efficient interaction between JNK and unphosphorylated c-Jun and the functional importance of the JNK-binding site strongly suggest that the two proteins associate in vivo. The binding of JNK to unphosphorylated c-Jun is likely to be responsible for increasing both the fidelity and efficiency of this phosphorylation reaction, taking place near the very end of a signaling cascade initiated at the cell surface. It is of interest that most, if not all, of the early steps in such signaling cascades also involve protein-protein interactions (Cantley et al. 1991) and that in bacteria the control of transcription by extracellular signals is based on physical interaction between a protein kinase and its substrate, a transcription factor (Albright et al. 1989). Such interactions are important for increasing both the speed and fidelity of information transfer.

Comparison of sites phosphorylated by some of the protein kinases involved in these pathways, especially the proline-directed kinases, suggests very little specific- ity (Moreno and Nurse 1990; Thomas 1992). However, these protein kinases must exhibit greater specificity in vivo. Although MAP kinases phosphorylate sites similar to those recognized by cell cycle-dependent kinases, the biological functions of these proteins and their substrates are entirely different (Thomas 1992). Genetic experiments indicate that the MAP kinases of budding yeast have different biological roles (Elion et al. 1990); and recently, one of them, FUS3, was found to associate tightly with several potential substrates (Elion et al. 1993). The association of protein kinases with their substrates is likely to have an important role in increasing the biological specificity of signal transduction by protein kinases.

Recently, transcription factor E2F was shown to associate with p107, cyclin A, and Cdk2 (Cao et al. 1992; Devoto et al. 1992; Pagano et al. 1992). This was suggested as a way to recruit Cdk2 to phosphorylate other DNA-binding proteins that interact with E2F-regulated promoters (for review, see Hunter and Karin, 1992; Nevins 1992). In addition, the c-Abl tyrosine kinase was reported to interact with transcription factor EP (Dikstein 
A

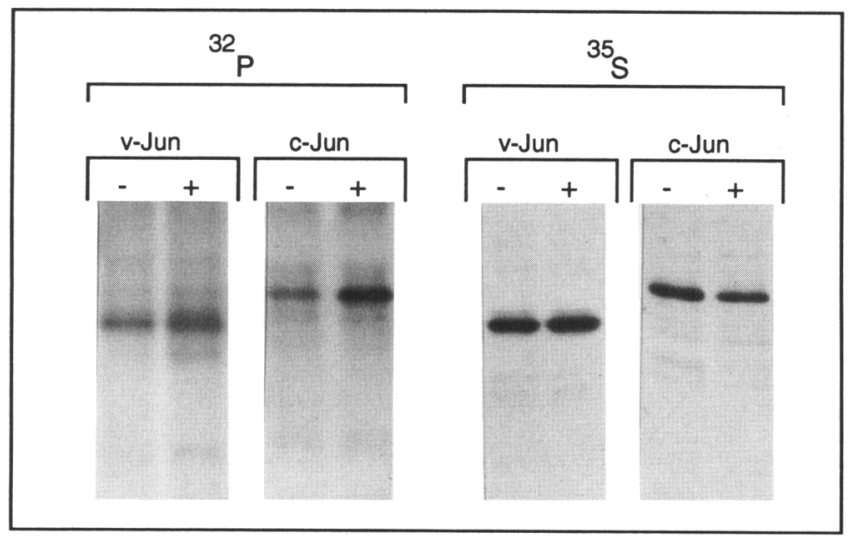

B

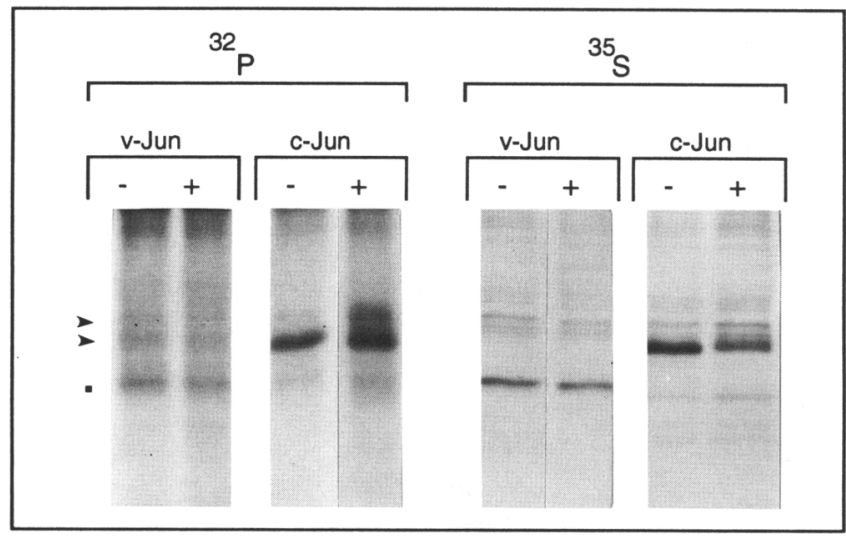

Figure 10. Differential phosphorylation response of c-Jun and v-Jun to Ha-Ras and UV. (A) Ha-Ras. v-Jun and c-Jun were isolated by immunoprecipitation from ${ }^{35} \mathrm{~S}$ - or ${ }^{32} \mathrm{P}$-labeled $\mathrm{F} 9$ cells transfected with $\mathrm{v}$-Jun and $\mathrm{c}$-Jun expression vectors in the absence or presence of pZIPNeoRas(Leu-61). The isolated proteins were analyzed by SDS-PAGE and autoradiography. Shown are the results of one typical experiment for each protein. Note that the ${ }^{32} \mathrm{P}$-labeled $\mathrm{v}$-Jun autoradiograph was exposed three times longer than the corresponding c-Jun autoradiograph. $(B)$ UV. v-Jun and c-Jun were isolated from ${ }^{32} \mathrm{P}$ - and ${ }^{35} \mathrm{~S}$-labeled $\mathrm{F} 9$ cells that were transfected with v-Jun or c-Jun expression vectors. One-half of the cells were irradiated with UV-C $\left(40 \mathrm{~J} / \mathrm{m}^{2}\right) 30 \mathrm{~min}$ before isolation of the Jun proteins by immunoprecipitation. In this case, the c-Jun- and v-Jun-labeled lanes represent equal autoradiographic exposures. The two arrowheads indicate the migration positions of the two forms of c-Jun (Devary et al. 1992); the square indicates the migration position of v-Jun.

et al. 1992). It was also reported that the $\mathrm{Ku}$ antigen, a nonspecific DNA-binding protein, associates with DNAdependent protein kinase, allowing it to phosphorylate proteins bound to DNA (Dvir et al. 1992; Gottlieb et al. 1993). In the same vein it is possible that c-Jun recruits INK to phosphorylate other components of the transcriptional machinery and thereby modulate their activity. JNK bound to c-Jun may phosphorylate other sequencespecific factors, such as Ets and NFAT, the binding sites of which reside next to AP-1 sites (Wasylyk et al. 1991; Jain et al. 1992). Both c-Ets1 and c-Ets2 and the related protein Erg contain potential JNK phosphorylation sites (Boulukos et al. 1988). c-Jun can interact with and modify the activity of a large number of other trans-activators even in the absence of DNA, including other bZIP proteins, nuclear receptors, and myogenic bHLH proteins (Diamond et al. 1990; Yang-Yen et al. 1990, 1991; Angel and Karin 1991; Hai and Curran, 1991; Bengal et al. 1992; Li et al. 1992). It is conceivable that after phosphorylating c-Jun, JNK may phosphorylate an adjacent protein, even though it does not bind to it directly. We have shown that JNK complexed with GSTcJun-GSHagarose is capable of phosphorylating an exogenous c-Jun protein added to these beads. It is of interest that c-Fos contains a sequence surrounding Thr- 232 that is very similar to the sequence surrounding Ser- 73 of c-Jun, which is an important part of the c-Fos activation domain (Sutherland et al. 1992). It is possible that by associating with c-Jun, c-Fos can be phosphorylated by JNK on Thr-232.

In summary, the tight association of JNK with c-Jun, although rarely precedented in eukaryotic systems, is likely to be of great regulatory importance not only for modulation of c-Jun activity but also for modulating the activity of other transcription factors. Experiments are in progress to test the occurrence of such interactions.

\section{Materials and methods}

Plasmids and expression of GST fusion proteins

GST-cJun expression vector, pGEX2T-clun(wt), was constructed by inserting a filled-in BspHI-Pst fragment (encoding amino acids 1-223) from RSV-cJun(BspHI) into the SmaI site of pGEX2T (Pharmacia). RSV-cJun(BspHI) was constructed by changing the translational initiator, CTATGA, of RSV-cJun to TCATGA by site-directed mutagenesis. pGEX2T-cJun(Ala63/ 73) was derived in the same manner from RSV-cJun(Ala63/73) (Smeal et al. 1991). The GSTcJun truncation mutants were constructed using the polymerase chain reaction (PCR) to amplify various portions of the c-Jun-coding region. The sequences of the primers are available on request. The v-Jun and chicken c-Jun sequences were derived from RCAS VC-3 and RCAS CJ-3, respectively (Bos et al. 1990). Fragments containing equivalent portions of c-Jun and v-Jun were cloned into pSG424, a GAL4 DNA-binding domain expression vector (Sadowski and Ptashne 1989).

The GST fusion protein expression vectors were transformed into the XL1-Blue or NM522 strains of Escherichia coli. Protein induction and purification were as described (Smith and Johnson 1988). The amount of purified fusion protein was estimated by the Bio-Rad protein assay.

\section{Cell culture and preparation of cell extracts}

FR3T3, Ha-ras-transformed FR3T3, HeLaS3, and QT6 cells were grown in Dulbecco's modified Eagle Medium (DMEM) containing $10 \%$ fetal calf serum (FCS), $100 \mathrm{U} / \mathrm{ml}$ of penicillin $(\mathrm{Pc})$, and $100 \mu \mathrm{g} / \mathrm{ml}$ of streptomycin (Sm). Jurkat, K562, and 
U937 cells were grown in RPMI 1640 supplemented with $10 \%$ FCS, $100 \mathrm{U} / \mathrm{ml}$ of $\mathrm{Pc}$, and $100 \mu \mathrm{g} / \mathrm{ml}$ of Sm. F9 cells were grown in $45 \%$ DMEM, $45 \%$ Ham's F- $12,10 \%$ FCS, $100 \mathrm{U} / \mathrm{ml}$ of Pc and $100 \mu \mathrm{g} / \mathrm{ml}$ of Sm. Nuclear and cytoplasmic extracts were prepared as described by Dignam et al. (1983). To prepare wholecell extract, harvested cells were suspended in WCE buffer $(25$ mM HEPES at $\mathrm{pH} 7.7,0.3 \mathrm{M} \mathrm{NaCl}, 1.5 \mathrm{~mm} \mathrm{MgCl}_{2}, 0.2 \mathrm{~mm}$ EDTA, $0.1 \%$ Triton X-100, $0.5 \mathrm{~mm}$ DTT, $20 \mathrm{~mm} \beta$-glycerolphosphate, $0.1 \mathrm{mM} \mathrm{Na} \mathrm{VO}_{4}, 2 \mu \mathrm{g} / \mathrm{ml}$ of leupeptin, $100 \mu \mathrm{g} / \mathrm{ml}$ of PMSF). The cell suspension was rotated at $4^{\circ} \mathrm{C}$ for $30 \mathrm{~min}$, and the extract was cleared by centrifugation at $10,000 \mathrm{~g}$ for $10 \mathrm{~min}$. Protein concentration was estimated by Bio-Rad protein assay.

\section{Solid-phase kinase assay}

Cell extracts were diluted so that the final composition of the WCE buffer was $20 \mathrm{mM}$ HEPES at $\mathrm{pH} 7.7,75 \mathrm{mM} \mathrm{NaCl}, 2.5 \mathrm{mM}$ $\mathrm{MgCl}_{2}, 0.1 \mathrm{~mm}$ EDTA, $0.05 \%$ Triton X-100, $0.5 \mathrm{~mm}$ DTT, 20 $\mathrm{mM} \beta$-glycerolphosphate, $0.1 \mathrm{mM} \mathrm{Na} \mathrm{VO}_{4}, 2 \mu \mathrm{g} / \mathrm{ml}$ of leupeptin, and $100 \mu \mathrm{g} / \mathrm{ml}$ of PMSF. The extracts were mixed with $10 \mu \mathrm{l}$ of GSH-agarose suspension (Sigma) to which $10 \mu \mathrm{g}$ of either GST or GSTJun were bound. The mixture was rotated at $4^{\circ} \mathrm{C}$ for $3 \mathrm{hr}$ in a microcentrifuge tube and pelleted by centrifugation at $10,000 \mathrm{~g}$ for $20 \mathrm{sec}$. After $4 \times 1-\mathrm{ml}$ washes in HEPES binding buffer (20 mM HEPES at $\mathrm{pH} 7.7,50 \mathrm{mM} \mathrm{NaCl}, 2.5 \mathrm{mM} \mathrm{MgCl}_{2}, 0.1$ mM EDTA, $0.05 \%$ Triton X-100), the pelleted beads were resuspended in $30 \mu \mathrm{l}$ of kinase buffer $20 \mathrm{~mm}$ HEPES at pH 7.6, $20 \mathrm{~mm}$ $\mathrm{MgCl}_{2}, 20 \mathrm{mM} \beta$-glycerolphosphate, $20 \mathrm{~mm}$ p-nitrophenyl phosphate, $0.1 \mathrm{mM} \mathrm{Na}_{3} \mathrm{VO}_{4}, 2 \mathrm{~mm}$ DTT) containing $20 \mu \mathrm{M}$ ATP and $5 \mu \mathrm{Ci}$ of $\left[\gamma^{-32} \mathrm{P}\right] \mathrm{ATP}$. After $20 \mathrm{~min}$ at $30^{\circ} \mathrm{C}$ the reaction was terminated by washing with HEPES binding buffer. Phosphorylated proteins were eluted with $30 \mu \mathrm{l}$ of $1.5 \times$ Laemlli sample buffer and resolved on $10 \%$ SDS-polyacrylamide gel, followed by autoradiography. Phosphate incorporation was determined by gel slicing and scintillation counting. Phosphorylated GST fusion proteins were eluted from gel slices and subjected to phosphopeptide mapping as described (Boyle et al. 1991).

\section{In-gel kinase assay}

In-gel kinase assays were performed as described by Kameshita and Fujisawa (1989) with slight modifications. c-Jun-binding proteins were isolated by using GSH-agarose beads containing $80 \mu \mathrm{g}$ of GSTcJun as described above. Proteins were eluted in Laemlli sample buffer and resolved on a 10\% SDS-polyacrylamide gel, which was polymerized in the absence or presence of GSTcJun $(40 \mu \mathrm{g} / \mathrm{ml})$. After electrophoresis, the gel was washed twice for $30 \mathrm{~min}$ with $100 \mathrm{ml}$ of $20 \%$ 2-propanol, $50 \mathrm{~mm}$ HEPES, at $\mathrm{pH} 7.6$ to remove SDS. The gel was then washed twice for 30 min with $100 \mathrm{ml}$ of buffer A $150 \mathrm{~mm}$ HEPES at $\mathrm{pH} 7.6,5 \mathrm{~mm}$ $\beta$-mercaptoethanol). It was then incubated in $200 \mathrm{ml}$ of $6 \mathrm{M}$ urea in buffer $\mathrm{A}$ at $25^{\circ} \mathrm{C}$ for $1 \mathrm{hr}$, followed by serial incubations in buffer A containing $0.05 \%$ Tween 20 and either $3,1.5$ or $0.75 \mathrm{M}$ urea. After washing several times, for $1 \mathrm{hr}$ each, with $100 \mathrm{ml}$ of buffer A containing $0.05 \%$ Tween 20 at $4^{\circ} \mathrm{C}$, the gel was incubated in kinase buffer containing $50 \mu \mathrm{M}$ ATP and $5 \mu \mathrm{Ci} / \mathrm{ml}$ of $\left[\gamma^{32} \mathrm{P}\right]$ ATP at $30^{\circ} \mathrm{C}$ for $1 \mathrm{hr}$. Finally, the gel was washed with 100 $\mathrm{ml}$ of $5 \%$ trichloroacetic acid and $1 \%$ sodium pyrophosphate at $25^{\circ} \mathrm{C}$ several times, followed by drying and autoradiography.

\section{Western blotting}

The different proteins and cell extracts were resolved by SDSPAGE on $10 \%$ gels, blotted onto Immobilon P transfer membranes (Millipore), and subjected to Western blotting analysis using an anti-ERK1/2 antiserum (691 from Dr. M. Cobb), or anti-phosphotyrosine antibodies /affinity-purified rabbit polyclonal from Dr. B. Sefton and mouse monoclonal 506 from Dr. J. Wang|. The antibody-antigen complexes were visualized by the enhanced chemiluminescence detection system (Amersham).

\section{Transfection experiments}

Transfection experiments were performed using RSV-cJun, RSV-vJun and GAL4-Jun, GAL4-vJun and Ha-Ras(Leu-61) expression vectors as described previously (Binetruy et al. 1991; Boyle et al. 1991; Smeal et al. 1991). Chloramphenicol acetyltransferese (CAT) activity was determined as described above. $\mathrm{c}$-Jun and v-Jun protein expression and phosphorylation were analyzed as described by Smeal et al. (1991, 1992).

\section{Acknowledgments}

We thank T. Deng, Y. Devary, Y. Ben-Neriah, B. Su, and T. Hunter for helpful discussions and the sharing of unpublished results. M. Cobb, T. Sturgill, M. Weber, J. Wang, B. Sefton, and $\mathrm{N}$. Tonks have kindly provided us with essential reagents. We also thank $T$. Hunter for his comments and $T$. Deng for constructing some of the expression vectors and phosphoamino acid analysis. This work was supported by grants MG 20 from the American Cancer Society, 3RT-0138 from the Tobacco-Related Disease Research Program, and DE-FG03-86ER60429 from the Department of Energy. M.H., A.L., and A.M. were supported by postdoctoral fellowships from The Institute for Cancer Research, Japan Society for the Promotion of Science, American Lung Association of California, and Tobacco-Related Disease Research Program.

The publication costs of this article were defrayed in part by payment of page charges. This article must therefore be hereby marked "advertisement" in accordance with 18 USC section 1734 solely to indicate this fact.

\section{References}

Adler, V., C.C. Franklin, and S. Kraft. 1992a. Phorbol esters stimulate the phosphorylation of c-Jun but not v-Jun: Regulation by the N-terminal delta domain. Proc. Natl. Acad. Sci. 89: 5341-5345.

Adler, V., A. Polotskaya, F. Wagner, and A.S. Kraft. 1992b. Affinity-purified c-Jun amino-terminal protein kinase requires serine/threonine phosphorylation for activity. J. Biol. Chem. 267: 17001-17005.

Alani, R., P. Brown, B. Binetruy, H. Dosaka, R.K. Rosenberg, P. Angel, M. Karin, and M.J. Birrer. 1991. The transactivating domain of the c-Jun proto-oncoprotein is required for cotransformation of rat embryo cells. Mol. Cell. Biol. 12: 6286-6295.

Albright, L.M., E. Hualu, and F.M. Ausubel. 1989. Prokaryotic signal transduction mediation by sensor and regulatory protein pairs. Annu. Rev. Genet. 23: 311-336.

Alvarez, E., I.C. Northwood, F.A. Gonzalez, D.A. Latour, A. Seth, C. Abate, T. Curran, and R.J. Davis. 1991. Pro-Leu-Ser/ Thr-Pro is a consensus primary sequence for substrate protein phosphorylation. I. Biol. Chem. 266: 15277-15285.

Angel, P. and M. Karin. 1991. The role of Jun, Fos and the AP-1 complex in cell-proliferation and transformation. Biochem. Biophys. Acta 1072: 129-157.

Angel, P., K. Hattori, T. Smeal, and M. Karin. 1988. The jun proto-oncogene is positively autoregulated by its product, Jun/AP-1. Cell 55: 875-885. 
Angel, P., T. Smeal, J. Meek, and M. Karin. 1989. Jun and v-Jun contain multiple regions that participate in transcriptional activation in an interdependent manner. New Biol. 1: 35-43.

Baichwal, V.R. and R. Tjian. 1990. Control of c-Jun Activity by interaction of a cell-specific inhibitor with regulatory domain $\delta$ : differences between v- and c-Jun. Cell 63: 815-825.

Baichwal, V.R., A. Park, and R. Tjian. 1991. v-Src and EJ Ras alleviate repression of c-Jun by a cell-specific inhibitor. $\mathrm{Na}$ ture 352: 165-168

- 1992. The cell-type-specific activator region of c-Jun juxtaposes constitutive and negatively regulated domains. Genes \& Dev. 6: 1493-1502.

Baker, S.J., T.K. Kerppola, D. Luk, M.T. Vandenberg, D.R. Marshak, T. Curran, and C. Abate. 1992. Jun is phosphorylated by several protein kinases at the same sites that are modified in serum-stimulated fibroblasts. Mol. Cell Biol. 12: 46944705 .

Bengal, E., L. Ransone, R. Scharfmann, V.J. Dwarki, S.J. Tapscott, H. Weintraub, and I.M. Verma. 1992. Functional antagonism between c-Jun and MyoD proteins: A direct physical association. Cell 68: 507-519.

Binetruy, B., T. Smeal, and M. Karin. 1991. Ha-Ras augments c-Jun activity and stimulates phosphorylation of its activation domain. Nature 351: 122-127.

Bohmann, D. and R. Tiian. 1989. Biochemical analysis of transcriptional activation by Jun: Differential activity of $\mathrm{c}$ - and v-Jun. Cell 59: 709-717.

Bos, T.J., F.S. Monteclaro, F. Mitsunobu, A.R. Ball, Jr., C.H. Chang, T. Nishimura, and P.K. Vogt. 1990. Efficient transformation of chicken embryo fibroblasts by c-Jun requires structural modification in coding and noncoding sequences. Genes \& Dev. 4: 1677-1687.

Boulton, T.G., S.H. Nye, D.J. Robbins, N.Y. Ip, E. Radziejewska, S.D. Morgenbesser, R.A. DePinho, N. Panayotatos, M.H. Cobb, and G.D. Yancopoulos. 1991. ERKs: a family of protein-serine/threonine kinases that are activated and tyrosine phosphorylated in response to insulin and NGF. Cell 65: 663-675.

Boulukos, K.E., P. Pognonec, A. Begue, F. Galibert, J.C. Gesquiere, D. Stéhelin, and J. Ghysdael. 1988. Identification in chickens of an evolutionarily conserved cellular ets-2 gene (c-ets-2) encoding nuclear proteins related to the products of the c-ets proto-oncogene. EMBO I. 7:697-705.

Boyle, W.J., T. Smeal, L.H.K. Defize, P. Angel, J.R. Woodgett, M. Karin, and T. Hunter. 1991. Activation of protein kinase C decreases phosphorylation of c-Jun at sites that negatively regulate its DNA-binding activity. Cell 64: 573-584.

Cantley, L.C., K.R. Auger, C. Carpenter, B. Duckworth, A. Graziani, R. Kapeller, and S. Soltoff. 1991. Oncogenes and signal transduction. Cell 64: 281-302.

Cao, L., B. Faha, M. Dembski, L-H. Tsai, E. Harlow, and N. Dyson. 1992. Independent binding of the retinoblastoma protein and p107 to transcriptional factor E2F. Nature 355: 176-179.

Chou, S.Y., V. Baichwal, and J.E. Ferrell, Jr. 1992. Inhibition of c-Jun DNA binding by mitogen-activated protein kinase. Mol. Biol. Cell 3: 1117-1130.

de Groot, R.P., J. Auwrex, M. Bourouis, and P. Sassone-Corsi. 1993. Negative regulation of Jun/AP-1: Conserved function of glycogen synthase kinase-3 and the Drosophila kinase shaggy. Oncogene 8: 841-847.

Devary, Y., R.A. Gottlieb, T. Smeal, and M. Karin. 1992. The mammalian ultraviolet response is triggered by activation of Src tyrosine kinases. Cell 71: 1081-1091.

Devoto, S.H., M. Mudryi, J. Pines, T. Hunter, and J.R. Nevins. 1992. A cyclin A-protein kinase complex possesses se- quence-specific DNA binding activity: $\mathrm{p} 33^{\text {cdk2 }}$ is a component of the E2F-cyclin A complex. Cell 68: 167-176.

Diamond, M.I., J.N. Miner, S.K. Yoshinaga, and K.R. Yamamoto. 1990. Transcription factor interactions: Selectors of positive or negative regulation from a single DNA element. Science 249: 1266-1272.

Dignam, J.D., R.M. Lebovitz, and R. Roeder. 1983. Accurate transcription initiation by RNA polymerase II in a soluble extract from isolated mammalian nuclei. Nucleic Acids Res. 11: 1475-1489.

Dikstein, R., D. Heffetz, Y. Ben-Neriah, and Y. Shaul. 1992. $\mathrm{c}$-abl has a sequence-specific enhancer binding activity. Cell 69: 751-757.

Dvir, A., S.R. Peterson, M.W. Knuth, H. Lu, and W.S. Dynan. 1992. Ku autoantigen is the regulatory component of a template-associated protein kinase that phosphorylates RNA polymerase II. Proc. Natl. Acad. Sci. 89: 11920-11924.

Elion, E.A., P.L. Grisafi, and G.R. Fink. 1990. FUS3 encodes a cdc2 $2^{+} / \mathrm{CDC} 28$-related kinase required for the transition from mitosis into conjugation. Cell 60: 649-664.

Elion, E.A., B. Satterberg, and J.E. Krantz. 1993. FUS3 phosphorylates multiple components of the mating signal transduction cascade: Evidence for STE12 and FAR1. Mol. Biol. Cell 4: 495-510.

Gottlieb, T.M, and S.P. Jackson. 1993. The DNA-dependent protein kinase: Requirement for DNA ends and association with Ku antigen. Cell 72: 131-142.

Hai, T. and T. Curran. 1991. Cross-family dimerization of transcription factors Fos/Jun and ATF/CREB alters DNA binding specificity. Proc. Natl. Acad. Sci. 88: 3720-3724.

Håvarstein, L.S., I.M. Morgan, W.Y. Wong, P.K. Vogt. 1992. Mutations in the Jun delta region suggest an inverse correlation between transformation and transcriptional activation. Proc. Natl. Acad. Sci. 89: 618-622.

Hunter, T. and M. Karin. 1992. The regulation of transcription by phosphorylation. Cell 70: 375-387.

Imler, J.L., E. Ugarte, C. Wasylyk, and B. Wasylyk, 1988. v-jun is a transcriptional activator, but not in all cell lines. Nucleic Acids Res. 16: 3005-3012.

Jain, J., P.G. McCaffrey, V.E. Valge-Archier, and A. Rao. 1992. Nuclear factor of activated $\mathrm{T}$ cells contains Fos and Jun. Nature 332: 275-278.

Kameshita, I. and H. Fujisawa. 1989. A sensitive method for detection of calmodulin-dependent protein kinase II activity in sodium dodecyl sulfate-polyacrylamide gel. Anal. Biochem. 183: 139-143.

Karin, M. and T. Smeal. 1992. Control of transcription factors by signal transduction pathways: The beginning of the end. Trend.

Biochem. Sci. 17: 418-422.

Kyriakis, J.M. and J. Avruch. 1990. pp54 microtubule-associated protein 2 kinase. J. Biol. Chem. 265: 17355-17363.

Li, L., J-C. Chambard, M. Karin, and E. Olson. 1992. Fos and Jun repress transcriptional activation by myogenin and MyoD: The amino terminus of Jun can mediate repression. Genes \& Dev. 6: 676-689.

Lillie, J.W. and M.R. Green. 1989. Transcription activation by the adenovirus Ela protein. Nature 338: $39-44$.

Lin, A., J. Frost, T. Deng, N. al-Alawi, T. Smeal, U. Kikkawa, T. Hunter, D. Brenner, and M. Karin. 1992. Casein kinase II is a negative regulator of c-Jun DNA binding and AP-1 activity. Cell 70: 777-789.

Moreno, S. and P. Nurse. 1990. Substrates for $\mathrm{p} 34^{\mathrm{cdc} 2}$ : in vivo veritas? Cell 61: 549-551.

Nevins, J.R. 1992. E2F: A link between the Rb tumor suppressor protein and viral oncoprotein. Science 258: 424-429. 
Hibi et al.

Pagano, M., G. Draetta, and P. Jansen-Dürr. 1992. Association of cdk2 kinase with the transcription factor E2F during $\mathrm{S}$ phase. Science 255: 1144-1147.

Pulverer, B.J., J.M. Kyriakis, J. Avruch, E. Nikolakaki, and J.R. Woodgett. 1991. Phosphorylation of c-jun mediated by MAP kinases. Nature 353: 670-674.

Pulverer, B.J., K. Hughes, C.C. Franklin, A.S. Kraft, S.J. Leevers, and J.R. Woodgett. 1992. Co-purification of mitogen-activated protein kinases with phorbol ester-induced c-Jun kinase activity in U937 leukaemic cell. Oncogene 7: 407-415.

Rossomando, A., D.M. Payne, M. Weber, and T.W. Sturgill. 1989. Evidence that pp42, a major tyrosine kinase target protein, is a mitogen-activated serine/threonine protein kinase. Proc. Natl. Acad. Sci. 86: 6940-6943.

Sadowski, I. and M. Ptashne. 1989. A vector for expressing GAL4(1-147) fusions in mammalian cells. Nucleic Acids Res. 17: 753 .

Smeal, T., P. Angel, J. Meek, and M. Karin. 1989. Different requirements for formation of Jun:Jun and Jun:Fos complexes. Genes \& Dev. 3: 2091-2100.

Smeal, T., B. Binetruy, D. Mercola, M. Birrer, and M. Karin. 1991. Oncogenic and transcriptional cooperation with HaRas requires phosphorylation of c-Jun on serines 63 and 73. Nature 354: 494-496.

Smeal, T., B. Binetruy, D. Mercola, A. Grover-Bardwick, G. Heidecker, U.R. Rapp, and M. Karin. 1992. Oncoprotein-mediated signalling cascade stimulates c-Jun activity by phosphorylation of serines 63 and 73. Mol. Cell. Biol. 12: 35073513.

Smith, S.B. and K.S. Johnson. 1988. Single-step purification of polypeptides expressed in Escherichia coli as fusions with glutathione S-transferase. Gene 67: 31-40.

Sutherland, J.A., A. Cook, A.J. Bannister, and T. Kouzarides. 1992. Conserved motifs in Fos and Jun define a new class of activation domain. Genes \& Dev. 6: 1810-1819.

Thomas, G. 1992. MAP kinase by any other name smells just as sweet. Cell 68: 3-6.

Vogt, P.K. and T.J. Bos. 1990. jun: Oncogene and transcription factor. Adv. Cancer Res. 55: 1-35.

Wasylyk, C., A. Gutman, R. Nicholson, and B. Wasylyk. 1991. The c-Ets oncoprotein activates the stromelysin promoter through the same elements as several non-nuclear oncoproteins. EMBO J. 10: 1127-1134.

Yang-Yen, H.F., J-C. Chambard, Y-L. Sun, T. Smeal, T.J. Schmidt, J. Drouin, and M. Karin. 1990. Transcriptional interference between c-Jun and the glucocorticoid receptor: Mutual inhibition of DNA binding due to direct proteinprotein interaction. Cell 62: 1205-1215.

Yang-Yen, H.F., X-K. Zang, G. Graupner, M. Tzukerman, B. Sakamoto, M. Karin, and M. Pfahl. 1991. Antagonism between retinoic acid receptors and AP-1: Implications for tumor promotion and inflammation. New Biol. 3: 1206-1219. 


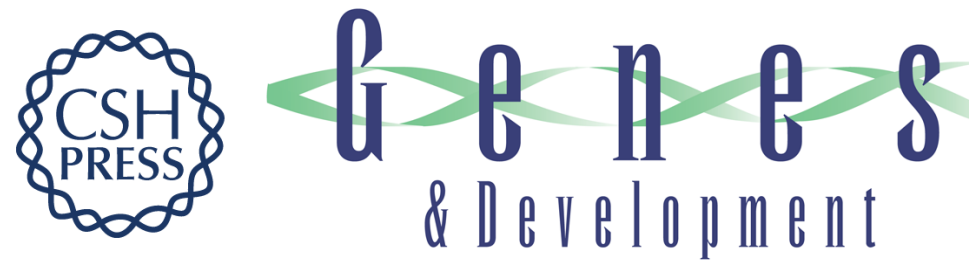

\section{Identification of an oncoprotein- and UV-responsive protein kinase that binds and potentiates the c-Jun activation domain.}

M Hibi, A Lin, T Smeal, et al.

Genes Dev. 1993, 7:

Access the most recent version at doi:10.1101/gad.7.11.2135

References This article cites 60 articles, 20 of which can be accessed free at:

http://genesdev.cshlp.org/content/7/11/2135.full.html\#ref-list-1

License

Email Alerting

Service

Receive free email alerts when new articles cite this article - sign up in the box at the top right corner of the article or click here.

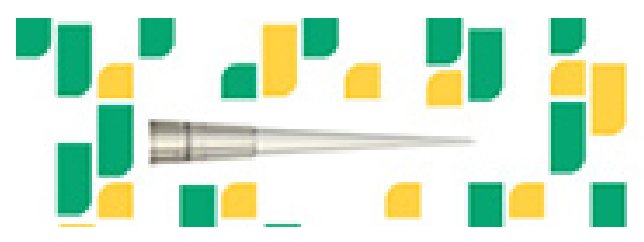

Focused on your science. 